\title{
UJI EFEK DIURETIK INFUS BIJI JAGUNG (Zea Mays L), RAMBUT JAGUNG DAN KOMBINASI ANTARA KEDUANYA PADA KELINCI JANTAN (Oryctolagus Cuniculus) BERDASARKAN PARAMETER FREKUENSI URINASI DAN VOLUME URIN
}

\author{
Hendra Herman, Rizqi Nur Azizah, Chikita Inaku \\ Fakultas Farmasi Universitas Muslim Indonesia \\ Email : hendrahermanapt@gmail.com
}

\begin{abstract}
Has been done research Diuretic effect test of seed corn infusem, hair Corn infuse and combination of both in order to determining diuretic effect with frequency urination and volume urine parameters. This research use trial animals as many as 15 male rabbits, divided into 5 groups and each group consisted of three tails, group I is control that given colloidal solution of Na.CMC $1 \%$, group II infuse corn (Zea mays L) $2333 \mathrm{mg}$ group III has Qvien seed corn infuse (Zee mays L) 466,664 gr, group IV has Given combination of hair and sedd corn infuse and group $V$ is comparator that given suspension of furosemid Treatment done orally with a dose of 20 / 2,5 kg for further observation and measurement frequency done diuretic and urine volume intervals of 1 hour for 5 hours after treatment The result showed that infuse of seed corn, hair corn and combination of both can increase the frequency of urination, and just infuse of seed corn and hair corn increase the volume win of rabbits This is supported by statistical analysis methods CRD (Completely Randomized Design) For the frequency of urination infuse of seed corn, hair corn, and combination of both did not significantly different with furecemid while for the volume urine hair corn infuse and seed corn infuse are significantly different with $\mathrm{Na}$ CMC and not significantly different with furosemid
\end{abstract}

Key words: Diuretic, seed and hair corn Infuse

\section{PENDAHULUAN}

Diuretik adalah obat yang bekerja pada ginjal untuk meningkatkan ekskresi air dan natrium Klorida. Sebagian besar bekerja dengan menurunkan reabsorbsi elektrolit oleh tubulus. Ekskresi elektrolit yang meningkat diikuti oleh peningkatan ekskresi air, yang penting untuk mempertahankan keseimbangan osmotik. Beberapa diuretik, secara luas digunakan pada terapi hipertensi (Neal, 2006). Salah satu penyebab penyakit hipertensi yakni, diakibatkan oleh asupan natrium tinggi dan peningkatan sirkulasi hormon 
natriuretik yang menginhibisi transport natrium intraseluler, menghasilkan peningkatan reaktivitas vascular dan tekanan darah (Yulinah, 2009).

Pada saat ini banyak obat sintetik yang digunakan untuk menangani hipertensi, yang memiliki efek samping yang besar, sehingga diperlukan usaha untuk mencari dan mengembangkan pengobatan dengan menggunakan bahan alam yang dapat memberikan efek terapi dengan efek samping yang kecil. Indonesia kaya akan sumber bahan obat alam dan obat tradisional yang telah digunakan oleh sebagian besar masyarakat Indonesia secara turun temurun. Keuntungan obat tradisional yang dirasakan langsung oleh masyarakat adalah kemudahan untuk memperoleh bahan bakunya dapat ditanam di pekarangan sendiri, murah dan dapat diramu sendiri di rumah (Zein, 2005). Jagung merupakan salah satu tanaman yang mudah ditemukan, tanaman ini masih digunakan sebagai bahan pokok makanan oleh masyarakat dan banyak yang menggunakannya sebagai bahan obat tradisional. Selain sebagai sumber karbohidrat, jagung juga merupakan sumber protein yang penting dalam menu masyarakat Indonesia. Bagian rambut mengandung saponin, zat samak, flavon, minyak atsiri, minyak lemak, alantoin, dan zat pahit. Bunga mengandung stigmasterol (Yuniarti, 2008).

Telah dilakukan penelitian tentang efek diuretika dekok daun jagung (Zea mays L.) terhadap marmot (Cavia porcellus) (Darman ,1994 ), Selain itu juga telah diteliti jus tongkol jagung muda yang menghasilkan volume urin $19 \mathrm{ml}$ dan dibandingkan dengan rebusan tongkol jagung muda hasilnya $28,17 \mathrm{ml}$ dan menggunakan control positif furosemid dengan jumlah urin yang didapat 31,83 $\mathrm{ml}$. Semuanya dilakukan pengamatan dalam waktu 5 jam dengan menggunakan hewan uji kelinci jantan (Kadir. N, 2009). Namun sampai saat ini belum ada informasi berupa penelitian ilmiah yang secara jelas menyebutkan bahwa kombinasi infus rambut dan biji jagung dapat memberikan efek Diuretik. Penggunaan masyarakat yang menggunakannya untuk mengatasi hipertensi dengan cara direbus jagung 5-7 tongkol, rambut jagung satu genggam, air $110 \mathrm{ml}$, diminum satu kali sehari $100 \mathrm{ml}$ (Yuniarti, 2008). Dalam penelitian ini mengggunakan metode penyarian dengan teknik penyarian infus berdasarkan pada 
penggunaan secara empiris di masyarakat yaitu dengan cara direbus.

\section{METODE PENELITIAN}

Penelitian dilaksanakan mulai bulan Juli sampai dengan Juni 2011, di Laboratorium Farmakologi Fakultas Farmasi Universitas Muslim Indonesia. Alat dan Bahan, Alat dan bahan yang akan digunakan disiapkan sesuai dengan kebutuhan penelitian.

\section{A. Prosedur Penelitian}

\section{Penyiapan bahan Penelitian}

Sampel yang akan digunakan adalah biji jagung dan rambut jagung (Zea mays L.) jagung muda diambil kemudian dibersihkan.

Dikeluarkan dari kelobotnya. Diambil rambut dan diambil biji dengan cara mengeluarkan dari tongkol (dipipil).

\section{Pembuatan Sampel}

Sampel yang digunakan Jagung (Zea mays L.), yakni bagian rambut dan bijinya. Rambut dan biji dicuci bersih,dikeluarkan dari kelobotnya dan tongkolnya dibuang. kemudian dirajang (dipotong-potong kecil) untuk memperbesar luas permukaan. Ada tiga macam sampel yang telah diujikan yakni rambut jagung biji jagung (Zea mays L.) dan kombinasi dari keduanya.

3. Pembuatan Bahan Penelitian

\section{a. Pembuatan Infus}

Infus yang dibuat yakni terdiri dari tiga macam. Pertama infus rambut jagung, kedua infus biji dan ketiga infus kombinasi dari biji dan rambut.

1) Pembuatan infus rambut jagung

Rambut Jagung sebanyak 23,33 mg dimasukan ke dalam panci infus selanjutnya ditambahkan air suling $100 \mathrm{ml}$, lalu dipanaskan selama 15 menit, dihitung mulai suhu dalam panci mencapai $90^{\circ} \mathrm{C}$ sambil sekali-sekali diaduk, selanjutnya diserkai selagi panas melalui kain flannel.

2) Pembuatan infus biji jagung

Biji jagung sebanyak 466,665 gr yang telah dirajang dimasukan ke dalam panci infus, kemudian ditambahkan air suling 


\begin{abstract}
$100 \mathrm{ml}$, lalu dipanaskan
selama 15 menit, dihitung mulai suhu dalam panci mencapai $90^{\circ}$ C sambil sekali-sekali diaduk, selanjutnya diserkai selagi panas melalui kain flannel.
\end{abstract}

3) Pembuatan Infus kombinasi rambut dan biji jagung

Biji Jagung
sebanyak 466,665 gr dan
rambut jagung sebanyak
23,33 mg yang telah
dirajang, Dimasukan ke
dalam panci infus.
Ditambahkan air suling
100 ml, lalu dipanaskan
selama 15 menit, dihitung
mulai suhu dalam panci
mencapai $90^{\circ}$ C sambil
sekali-sekali diaduk,
selanjutnya diserkai
selagi panas melalui kain
flannel.

b. Pembuatan

larutan koloidal Na-CMC $1 \%$ b/v (Parrot, 1980)

Sebanyak 1 gram NaCMC dimasukan sedikit demi sedikit ke dalam $50 \mathrm{ml}$ air suling panas $\left(70^{\circ} \mathrm{C}\right)$ sambil diaduk dengan pengaduk elektrik hingga terbentuk larutan koloidal. Volumenya dicukupkan hingga $100 \mathrm{ml}$ dengan air suling.

c) Pembuatan suspensi furosemid

Sebanyak 20 tablet furosemid (40 $\mathrm{mg} /$ tablet) ditimbang kemudian dihitung bobot rata-rata tiap tablet, dimasukan ke dalam lumpang dan digerus sampai halus. Sebanyak 94,07 mg serbuk tablet (setara dengan 4,667 mg furosemid) ditambah $\mathrm{Na}$ CMC $1 \%$ sedikit demi sedikit sambil digerus sampai homogen lalu dimasukan dalam labu terukur $100 \mathrm{~mL}$ dan dicukupkan volumenya dengan $\mathrm{Na}-\mathrm{CMC} 1 \%$ hingga $100 \mathrm{ml}$.

4. Pemilihan dan Penyiapan Hewan Uji

\section{a. Pemilihan Hewan Uji}

Hewan uji yang digunakan adalah kelinci jantan yang dewasa, sehat dan bersih dengan berat badan 1,5-2,5 $\mathrm{Kg}$. sebelum perlakuan hewan-hewan tersebut di adaptasikan 
dengan lingkungan

sekitarnya minimal selama 2 minggu.

b. Penyiapan hewan uji

Sebanyak 15 ekor Kelinci jantan yang dibagi dalam 5 kelompok yaitu 3 kelompok perlakuan yang diberi infus dan 1 kelompok sebagai control pembanding yang diberi suspensi furosemid dan 1 kelompok sebagai kontrol negatif.

Sebelum perlakuan hewan Uji telah dipuasakan semalam sebelum perlakuan atau minimal 8 jam agar lambung dari Hewan Percobaan kosong sebelum perlakuan dan tidak mempengaruhi hasil yang akan dicapai. Setelah itu Hewan Uji ditimbang berat badannya, untuk disesuaikan dengan volume pemberian, kemudian hewan Uji diberi tanda.

c. Perlakuan terhadap Hewan Uji

Hewan uji diberikan infus biji, infus rambut (Zea mays L.), dan infus kombinasi dari keduanya, suspensi furosemid, dan
Larutan koloidal Na-CMC $1 \% \mathrm{~b} / \mathrm{v}$, secara oral. Jumlah Volume obat yang diberikan disesuaikan dengan Volume Pemberian dari masingmasing Hewan Uji, dan Volume pemberian disesuaikan dengan berat badan kelinci.

Pemberian dilakukan dengan cara mouth block dimasukan kedalam mulut kelinci, kemudian dimasukan selang karet (kateter) ke dalam oesofagus, lubang kerongkongan melalui lubang mulut. Kateter dimasukan lebih kurang 20$25 \mathrm{~cm}$ sampai kedalam lambung. Kemudian alat suntik (spoit) dihubungkan dengan kateter dan dimasukan sampel dan disemprotkan kedalam lambung.

Dari setiap kelompok diambil semua hewan Uji, lalu diukur dengan menggunakan dua parameter yaitu frekuensi Diuretik dan volume urin dan dibandingkan dengan control Na-CMC dan pembanding (suspensi 
Uji Efek Diuretik Infus Biji Jagung, Rambut Jagung Dan Kombinasi Antara Keduanya

$\begin{array}{ll}\text { furosemid). } \quad \text { Waktu } & 240 \text { menit, } 300 \text { menit, dan } \\ \text { pengamatan adalah } 60 & 360 \text { menit atau selama } 5 \\ \text { menit, } 120 \text { menit, } 180 \text { menit, } & \text { jam. }\end{array}$

\section{HASIL PENELITIAN}

Tabel 1. Data frekuensi Diuretik (kali) dan volume Urin kelinci jantan selama 5 jam

\begin{tabular}{|c|c|c|c|c|c|c|c|c|}
\hline \multirow{2}{*}{ Perlakuan } & \multirow{2}{*}{ Kelinci } & \multicolumn{5}{|c|}{ Jam ke } & \multirow{2}{*}{$\begin{array}{l}\text { Volume } \\
\text { Total }(\mathrm{ml})\end{array}$} & \multirow{2}{*}{ Frekuensi } \\
\hline & & 1 & 2 & 3 & 4 & 5 & & \\
\hline \multirow{4}{*}{$\mathrm{Na} \mathrm{CMC}$} & 1 & 0 & 0 & 74 & 0 & 0 & 74 & 1 \\
\hline & 2 & 0 & 0 & 0 & 0 & 0 & 0 & 0 \\
\hline & 3 & 0 & 0 & 0 & 0 & 0 & 0 & 0 \\
\hline & & & & & & & 74 & \\
\hline \multirow{4}{*}{$\begin{array}{l}\text { Infus } \\
\text { Rambut } \\
\text { jagung }\end{array}$} & 1 & 0 & 0 & 35 & 0 & 146 & 181 & 2 \\
\hline & 2 & 0 & 0 & 162 & 0 & 0 & 162 & 1 \\
\hline & 3 & 0 & 0 & 0 & 0 & 154 & 154 & 1 \\
\hline & & & & & & & 497 & \\
\hline \multirow{4}{*}{ Infus Biji } & 1 & 0 & 0 & 0 & 0 & 120 & 120 & 1 \\
\hline & 2 & 0 & 0 & 0 & 0 & 116 & 116 & 1 \\
\hline & 3 & 0 & 0 & 0 & 0 & 115 & 115 & 1 \\
\hline & & & & & & & 351 & \\
\hline \multirow{4}{*}{$\begin{array}{c}\text { Infus } \\
\text { Rambut } \\
\text { dan biji }\end{array}$} & 1 & 0 & 0 & 78 & 0 & 25 & 103 & 2 \\
\hline & 2 & 0 & 0 & 0 & 90 & 0 & 90 & 1 \\
\hline & 3 & 0 & 0 & 0 & 85 & 0 & 85 & 1 \\
\hline & & & & & & & 288 & \\
\hline \multirow{4}{*}{ Furosemid } & 1 & 0 & 0 & 0 & 94 & 33 & 127 & 2 \\
\hline & 2 & 0 & 0 & 0 & 155 & 0 & 155 & 1 \\
\hline & 3 & 0 & 0 & 141 & 0 & 0 & 141 & 1 \\
\hline & & & & & & & 423 & \\
\hline
\end{tabular}

\section{PEMBAHASAN}

Jagung merupakan salah satu tanaman yang bisa dijadikan sebagai makanan pokok. Tanaman ini pun memiliki fungsi dalam pengobatan yang telah digunakan secara empiris yakni batu empedu, batu ginjal, tekanan darah tinggi, hepatitis, kencing manis, sirosis.

Penelitian uji efek Diuretik infus biji jagung (Zea mays L.), rambut jagung (Zea mays L.) dan kombinasi diantara keduanya dilakukan dengan menggunakan 2 paramater yakni volume urin dan frekuensi pengeluaran urin yang dilihat pada hewan uji kelinci jantan (Oryctolagus cuniculus). Penelitian ini menggunakan Hewan uji sejumlah 15 ekor yang telah diadaptasikan selama 2 minggu dibagi dalam 5 kelompok, masing-masing kelompok terdiri dari 3 ekor hewan uji. kelompok I merupakan kelompok kontrol yang telah diberi larutan koloidal Na-CMC 1\%, yang dipilih sesuai dengan media sampel yang 
digunakan untuk mengetahui ada atau tidaknya pengaruh larutan tersebut. Kelmpok II diberikan infus rambut jagung kelompok III diberikan infus biji jagung, kelompok IV infus kombinasi dari keduanya, dan kelompok $\mathrm{V}$ diberi suspensi furosemid.

Hasil pegujian efek diuretik dengan menggunakan dua parameter volume urin $(\mathrm{ml})$ menunjukan bahwa infus rambut jagung (Zea mays L.) dengan hasil volume total $497 \mathrm{ml}$, kemudian infus biji jagung (Zea mays L.) dengan hasil volume total $351 \mathrm{ml}$, sedangkan untuk infus kombinasi dari rambut dan biji jagung (Zea mays L.) memberikan hasil volume total sebanyak $288 \mathrm{ml}$. jadi infus biji jagung (Zea mays L.), tidak berbeda jauh dengan kontrol positif furosemid sedangkan rambut jagung (Zea mays L.), yang memberikan efek diuretik paling besar dan melebihi kontrol positif furosemid yang memberikan hasil volume total sebanyak $423 \mathrm{ml}$.

Selain volume urin total, dapat dilihat hasil frekuensi urinasi (kali) dari kelinci jantan (Oryctolagus cuniculus) pada infus rambut jagung (Zea mays L.) total frekuensinya sebanyak 4 kali, untuk pemberian infus biji jagung (Zea mays L.) sebanyak 3 kali, dan infus kombinasi dari rambut dan biji (Zea mays L.) memberikan hasil frekuensi sebanyak 3 kali. Dapat dikatakan bahwa infus rambut yang memberikan frekuensi sama seperti kontrol positif furosemid sebanyak 4 kali.

Berdasarkan parameter pengukuran volume urin dan dan frekuensi urinasi yang telah dianalisis dengan uji statistik RAL, dimana untuk melihat pengaruhnya dapat dilihat pada table Anava nilai $\mathrm{FH}>\mathrm{F}$ table pada taraf $5 \%$ dan taraf $1 \%$ untuk perlakuan adalah signifikan atau ada pengaruh pemberian Infus Biji jagung, Infus rambut Jagung dan Kombinasi antara keduanya Terhadap Volume Urin.

Untuk Data Volume Urin, Analisis dilanjutkan dengan Uji Duncan yang menunjukan bahwa infus biji jagung dan rambut jagung sangat berbeda nyata dengan $\mathrm{Na} C \mathrm{CMC} 1 \%$, Selanjutnya Infus biji jagung dan infus rambut jagung non signifikan atau tidak memiliki perbedaan yang nyata dengan furosemid.

Untuk parameter frekuensi Diuretik, infus rambut jagung, infus biji jagung (Zea mays L.), dan infus kombinasi dari keduanya, memiliki frekuensi urinasi yang berbeda nyata denga $\mathrm{Na} \mathrm{CMC}$, namun tidak berbeda nyata dengan furosemid. Hal ini menunjukan bahwa semua infus 
tersebut dapat meningkatkan frekuensi urinasi.

Dari hasil Penelitian yang telah dilakukan berdasarkan kedua parameter pengujian, infus biji jagung, infus rambut jagung, dan kombinasi dari keduanya mempunyai efek diuretik, dimana ketiganya dapat meningkatkan frekuensi Urinasi namun hanya Infus Biji dan Rambut Jagung yang dapat meningkatkan Volume Urin yang ditunjukan secara statistik tidak berbeda nyata dengan furosemid.

\section{KESIMPULAN}

1. Infus biji jagung, infus rambut jagung (Zea mays L.), dan kombinasi dari keduanya memiliki efek diuretik.

2. Infus biji jagung, infus rambut jagung (Zea mays L.), dan kombinasi dari keduanya dapat meningkatkan frekuensi Urinasi kelinci Jantan (Oryctolagus cuniculus)

3. Infus biji jagung dan infus rambut jagung (Zea mays L.) yang dapat meningkatkan Volume Urin kelinci Jantan (Oryctolagus cuniculus)

\section{DAFTAR PUSTAKA}

Argo Subekti Nuning, dkk. 2011. Morfologi Tanaman dan Fase .Pertumbuhan Jagung. Pustaka litbang DEPTAN
Balai Penelitian Tanaman Serealia : Maros.

Darman. 1994. Uji Efek Diuretika Dekok Daun Jagung (Zea mays L.) terhadap marmot (Cavia porcellus) Universitas Hasanudin. Tidak diterbitkan: Makassar

Dirjen POM. 1995. Farmakope Indonesia Edisi III. Depkes RI: Jakarta., hlm. 3

Dirjen POM. 1995. Material medika Indonesia jilid VI. Depkes RI: Jakarta., hlm. 142

Parrot, Eugene C. (1980). Pharmaceutical Technology . Collage of Pharmacy University of lowa: lowa City., hlm.353

Haryono. 1986. Sediaan Galenik. Departemen Kesehatan Republik Indonesia:Jakarta, 8.

ITIS. 2011. Integrate Taxonomic Information Syste. Taxonomic Zea mayys L. (on Line)

www.itis.gov/glossary.html. diakses tgl 19 november 2011

Kadir,N. 2009. Uji Efek diuretik Tongkol Jagung (Zea mays L.) terhadap kelinci jantan (Oryctolagus cuniculus). Tidak diterbitkan, Fakutas Farmasi Universitas Hasanudin Makassar: Makassar., hlm. 4

Kumar, et al. 2010. Free Radical Scavenging Property and Diuretik effect of triglize, a polyherbal formulation in 
Uji Efek Diuretik Infus Biji Jagung, Rambut Jagung Dan Kombinasi Antara Keduanya

experimental models.

Departemen of

pharmacology, TIFAC-

CORE, J.S.S College of

pharmacy chenai: india. (on

line). ( http://

www.jpharmacol.com on

Tuesday, march 01, 2011)

Harcourt-Brown, Frances. 2002.

Textbook of rabbit medicine.

Alden Press: Oxford

Lullman,H.et al. 2005. Color Atlas of Pharmacology 3th edition, revised and expanded. Thieme Stuttgart: New York., HIm. 162

Mutschler, E. 1999. Dinamika Obat buku ajar Farmakologi dan Toksikologi. ITB: bandung., hlm. 565

Nafrialdi. 2009. Farmkologi Terapi edisi $V$ (Cetak ulang). Departemen farmakologi dan terapeutik. Universitas Indonesia: Jakarta., hlm. 389-401

Neal,J.M. 2006. Farmakologi Medis edisi V. Erlangga: Jakarta., hlm. 34-35

Steenis,V, dkk. 2008. Flora untuk sekolah di Indonesia. Pradnya Paramita: Jakarta., hlm. 41-42

sukandar,E.Y.,dkk. 2009. ISO Farmakoterapi. PT. ISFI Penerbitan: Jakarta., HIm. 119

Tjay,T.H. 2008. Obat-obat Penting Khasiat Penggunaan dan
Efek-efek Sampingnya.

Gramedia: Jakarta., hlm. 519-521

Tjitrosoepomo, G. 2005. Taksonomi Tumbuhan Obat-Obatan. Gadja madah university press: Yogyakarta., hlm.113415

Utariningsih,DKK., 2007. Dekok Rambut Jagung (Zea mays) Efektif dalam menurunkan Kadar Kolesterol Tikus Putih (Rattus norvegicus) universitas muhammadiyah malang. Tidak diterbitkan : Malang., hlm. 4

Darman.,1994. Efek Diuretika Dekok Daun Jagung (Zea mays L.) Terhadap Marmot (Cavia porcellus) Universitas Hasanudin. Tidak diterbitkan: Makssar

Warisno. 2003. Budi Daya Jagung Hibrida. Kanisius: yogyakarta

Williams, Wilkins. 2009. Lippincott's Illustrated Reviews:

Pharmacology, $4^{\text {th }}$. Lippincott-Raven Publisher: east washinton square Philadelpia., hlm. 264

Yuniarti,T. 2008. Ensiklopedia tanaman Obat tradisional. MedPress: Yogyakarta., HIm. 134

Zein,U. 2005. Pemanfaatan Tumbuhan Obat dalam Upaya Pemeliharaan Kesehatan. Universutas USU e-usu repository: Sumatra Utara., hlm. 1 